\title{
Gender Diversity and Firm Value: Evidence from UK Financial Institutions
}

\author{
Accepted for Publication in July 2017 \\ ${ }^{1}$ Peter Agyemang-Mintah \\ ${ }^{2}$ Hannu Schadewitz
}

${ }^{1},{ }^{2}$ Turku school of Economics, University of Turku-Finland Department of Accounting and Finance, Rehtorinpellonkatu 3, 20500 Turku Postal Address: 20014 Turun yliopisto Finland 


\begin{abstract}
Purpose: The purpose of this research is first, to empirically examine if the appointment of females (Board Gender Diversity) onto the corporate boards of UK financial institutions can improve the firm's value. The second purpose is to examine if having females on the boards of UK financial institutions can impact the firm's value during the pre/post global financial crisis situation.
\end{abstract}

Design/methodology/approach: The paper uses secondary data obtained from DataStream covering 63 financial institutions over a period of 12 years. A number of additional statistical estimations, including Random Effects and Fixed Effects, are conducted in order to test the robustness of the findings.

Findings: The outcome of this empirical research shows that the presence of females on the corporate boards of UK financial institutions has a positive and statistically significant relationship to the firm's value. Before the financial crisis era, that is, during the pre-crisis situation (2000-2006), our evidence reveals a positive and statistically significant impact on the firm's value. This means that women contributed significantly to the firm's value. However, after the financial crisis period, the presence of females on the board did not make any significant effect on the firm's value. A reasonable explanation may be that, even though the financial crisis was over from 2009 to 2011, the entire UK economy was still experiencing an economic downturn and financial firms were no exception, irrespective of whether there was female representation on any corporate board. Overall, the findings are consistent with prior studies.

Originality/value: In spite of several research projects on board gender diversity (BGD), this research is unique when compared to other previous empirical works because, primarily, it will be the first time that such research will empirically ascertain board gender diversity and firm value in UK financial institutions and also during the pre/post financial crisis era. This paper contributes to the corporate governance literature by offering new insights on board diversity and firm's value relationship. Overall, the results will help to fill any missing gaps on gender diversity and firm's value in UK financial institutions.

Keywords: Gender diversity, firm's value, UK, financial institutions, financial crisis

Paper type: Research paper

\title{
1. Introduction
}

One of the modus operandi of the nomination committee is the appointment of males onto the corporate board. The continuous appointment of male candidates at the expense of females creates the impression that knowledge, talent, skills, experience and ability to address corporate issues are only vested in the hands of men. When the nomination committee appoints males and females into the corporate board with the aim of balancing divergent views and improving a firm's financial performance, we define it as board gender diversity (BGD). The presence of female representation on the corporate board is so important that, in December 2013, Twitter 
came under pressure from the media for neglecting to have any women on its board. The CEO responded that the appointment of board members should not be a matter of just 'checking a box'. The company later appointed Marjorie Scardino as the first female director on the board. Twitter took a bold step in addressing this issue ${ }^{3}$ (Sila et al. 2016).

Board gender diversity (BGD) has become an issue for discussion because of four benefits that a firm tends to gain when having a more gender diverse board, which are: improving financial performance; opportunities to attract a wider pool of talent; becoming more responsive to the market; and, finally, the ability to strengthen its corporate governance policies (Doldor et al. 2012).

Generally, the debate on gender diversity involves two arguments. The first argument holds the view that women with competent skills, experience and qualifications deserve the opportunity to serve on corporate boards. The second argument suggests that positive gender diversity amongst corporate directors results in better governance and enhances the performance of a firm. This second proposition means that the representation of females on the board should serve solely to improve performance, otherwise firms will be engaging in 'tokenism', which is the practice of representing a small group or minority on a board in order to give an appearance of sexual or racial equality within a workforce (Kanter, 1977). Here, firms make a perfunctory gesture of inclusiveness towards minority groups (Zimmer, 1988). If the nomination committee can argue that it is important to have females on the corporate board, it will be easier for them to build a business case about their competency to the shareholders (Carter et al. 2010; Patterson, 1997).

This research will toe the line of the second debate above and set the first objective or the purpose of this research by empirically examining if the appointment of females onto UK financial institutions' boards can improve firm value. Supporting this research purpose is a study by Cotter et al. (2001) which indicate that, although women are equipped with both the skills and qualifications needed to be appointed to the board, the board intentionally discriminates against them based on stereotypes which are unrelated to their experience and qualifications. Another assertion, by Hillman et al. (2002), argues that women have different backgrounds and characteristics that make them unique when compared with traditional directors. Kramer et al. (2007) indicate that women are known to ask tough questions and bring unity into leadership positions.

Further, research by Terjesen et al. (2009) also reveals that diversity in boards brings unique human capital and helps enhance board independence. This is also supported by McLeod and Lobel (1992), who argue that individuals with different opinions from diverse groups can improve the quality of decision-making and take into account the views of underrepresented groups. Perryman et al. (2016) suggested that, the heterogeneity in decision-making by the corporate boards helps to solve problems and enhances the presence of better decision-making because the board can engage in the critical analysis of issues. Studies by (Faff et al. 2011) using psychometric data indicate that women are more risk averse than men in general business and financial decision making. This makes women less risk tolerant than men during an investment decision. Firms can therefore balance their risk tolerance when they have a combination of female and male on the corporate board for decision making.

A survey by Catalyst (2011) points out that Fortune 500 firms with women on the corporate board outperformed those without females between 2004 and 2008.

${ }^{3}$ http://www.wired.com/2013/12/twitter-board-bumbled-gender-issues/, accessed on 10/02/2016. 
Rose (2007) argues that a high degree of board diversity may serve as a positive signal to prospective job applicants looking to join a company. For example, physically disabled people and gender minorities will realise that they have a chance in the highest positions within the firm. This means access to a wide pool of talented individuals who are able to apply for positions, thereby increasing transparency and good corporate governance (Davies Report, 2011).

The first motivation for this research is that, there have also been various corporate governance reforms in the UK all aimed at incorporating women into the corporate boardroom in order for them to contribute to the decision-making process. Examples of such reforms are: the Higgs Review 2003; Tyson Report 2003; and Walker Review 2009. Additionally, in 2011, another independent review on women conducted by Lord Davies (2011) and commissioned by the UK government recommended that FTSE 100 firms should aim for a minimum of $25 \%$ female board member representation by 2015 in order to attract talented and gifted women to fill the top jobs across the UK. In response to the Davies Report (2011), the UK Financial Reporting Council (FRC, 2014) published a report requiring firms to annually report their boardroom diversity policies and to include gender diversity in the assessment of board effectiveness and efficiency. The report from the FRC (2014) demonstrates that diversified boards enhance the balance of skills, experience and knowledge available from different people. The empirical outcome of this research will help support various reforms which have taken place (Lord Davies 2011; FRC, 2014 report).

The second motivation is that, despite the various corporate governance reforms in the UK, the appointment of women into the corporate boardroom still remains voluntary, which means the board is not obliged to consider female gender representation as an alternative to assist board success (FRC, 2014). The voluntary nature of implementing the UK Corporate Governance Code makes an empirical study worth pursuing.

The third motivation is that board gender diversity is not only an issue to firms but is also an issue to several countries. For example, the European Commission (EC) has been considering imposing quotas for female representation on corporate boards across the EU. In addition, Norway and Spain have introduced legislation where a quota applies when selecting women for board membership (Adams and Ferreira, 2009), Malaysia has imposed a 30\% quota and Brazil targets $40 \%$ for state-controlled firms (The Economist, 2014). The implementation of gender diversity in the UK is in fulfilment of EU policy.

The four motivation looks at the lobbying groups such as Women Corporate Directors (WCD), who actively push for more women to be present in the boardroom ${ }^{4}$. The outcome of this paper will provide empirical support to any group interested in gender issues and contribute immensely to the gender research gap.

In pursuing research on gender diversity in UK financial institutions, another interesting path is that the UK financial sector is the second-biggest financial centre after the US and is considered the European hub for financial services. The sector offers financial services products such as banking, insurance, mortgages, asset management and mutual funds to all stakeholders (HM Treasury 2015; Mintah and Schadewitz, 2015). Financial institutions in the UK are more heavily controlled by the government and other international bodies than other sectors of the economy due to their high capital structure and their immense economic contributions to national development. For example, according to the Office for National

4 (http://www.womencorporatedirectors.com, WomenCorporateDirectors, accessed on 06/02/2016. 
Statistics (ONS) in 2015, UK financial firms constituted 78.4\% of UK GDP ${ }^{5}$ (Yermack 1996; Guest 2009; Lim et al. 2007; Levine 2003; Mintah 2015).

Due to the economic benefit of UK financial institutions, this research will also look at a second objective or purpose, where the effect of women (BGD) on the boards of UK financial firms will be examined during the pre/post global financial crisis situation. Arguably, these motivations uniquely provide an impetus to investigate the extent to which board diversity influences a firm's financial performance. To the best of our knowledge, this study constitutes one of the first attempts at estimating the impact of board diversity on UK financial firms; this will help fill any gap in the board gender diversity (BGD) literature and serve as a stepping stone for further research.

Based on the above arguments, this paper will investigate the crucial policy questions of: firstly, whether women (gender diversity) within the board influence the firm's financial performance. Secondly, what is the impact of BGD on the value of a firm during the pre/post financial crisis periods? The empirical results to these questions have shown that BGD is positively and statistically significant to the firm's value. Further studies on BGD show a positive and statistically significant relationship to the firm's value during the pre-crisis period. By contrast, we do not find any evidence of a significant relationship during the post-global financial crisis period.

Overall, our findings are consistent with agency, stakeholder and resource dependence theories, which suggest that gender diversity enhances board monitoring and brings diversity in ideas, new perspective, experience and business knowledge to the decision-making process in boardrooms, thereby improving the firm's financial valuation.

The next section discusses the related literature review, including theoretical perspective, financial crisis, prior empirical studies and hypotheses development.

\section{Related Literature Review}

\subsection{Theoretical Background}

Research on board gender diversity (BGD) has a mixed theoretical proposition. This means that there is no single theory predicting the relationship between women on the corporate board and firm financial performance (Carter et al. 2010). However, the first and most dominant theory used in supporting BGD research is Agency Theory.

First, Agency Theory deals with the separation of ownership from control, and the relationship that exists between the principal/owner and the manager/agent (Berle and Means, 1932; Jensen and Meckling, 1976). Boards with diverse backgrounds (male and female) perform strategic functions such as monitoring and advising, and bringing diversity in ideas, perspective, experience and business knowledge to the decision-making process in boardrooms, which will eventually increase firm performance (Johnston and Malina, 2008; Lincoln and Adedoyin, 2012; Triana et al. 2013; Baranchuk and Dybvig, 2009; Ntim, 2013; Khosa, 2014). All boards

\footnotetext{
${ }^{5}$ http://www.ons.gov.uk/ons/rel/gva/gross-domestic-product--preliminary-estimate/q1-2015/stb-gdppreliminary-estimate--q1-2015.html. Accessed 05/02/16.
} 
are formed to overcome agency problems and help enhance the board's effectiveness. A diversified board may help enhance the role of women in aligning the interests of management with those of the shareholders (Hillman and Dalziel, 2003). Gender diversity, according to Low et al. (2015), improves board monitoring because hiring directors from different backgrounds gives a different lens to the firm where the female members can challenge the status quo (Yi, 2011). A gender-diverse board is more fruitful in its monitoring roles, as women tend to question management practices and challenge conventional wisdom (Adams and Ferreira, 2009; Carter et al. 2003). Furthermore, due to the nature of women's unique experience, expertise and specialised knowledge, and distinctive social and business ties, they can help to provide access to both additional resources and market insight, rendering female directors invaluable to the board (Konek, 1994; Thomson et al. 2005; Wittenberg-Cox and Maitland, 2008). Adams and Ferreira (2009) argue that women on corporate boards introduce tougher monitoring, as they do not belong to the "old boys' club" network, and also demonstrate improved attendance rates over their male counterparts.

The empirical contribution suggests that a diverse board impacts positively and has a statistically significant relationship to the firm's value even in better-governed firms. As firms appoint women directors, they see an increase in their firm's value as a result of extra monitoring, which in turn, may reduce the extent of agency problems (Ntim, 2013). Our results are consistent with agency theory predictions.

The second theory deals with the Stakeholder Model, which states that corporations should maximise the welfare of a number of the firm's stakeholders instead of only its shareholders. Stakeholders include employees, either male or female, customers, creditors, debtors, local communities and the government (Blair, 1995; Finegold et al. 2007). Stakeholder theory suggests that inclusive support is offered by all members in which each group can be seen as supplying the firm with important resources in return for the expectation that their interests will be promoted (March and Simon, 1958; Hill and Jones, 1992; Jensen, 2001, 2002).

As stakeholders might have different expectations to those perceived by shareholders, they might suggest that the boardroom composition should be adjusted to reflect the expectations of all stakeholders, such as through the appointment of female directors (Low et al. 2015; Blair 1995; Finegold et al. 2007). For example, customers and the government may use their shareholding rights to push for diverse boards because of the need for social integration (Dams and Scholtens, 2012; Ntim, 2013).

The empirical results suggest that the presence of women on the boards of UK financial institutions contributed positively to the firm's value. The attainment of these empirical results has reaffirmed the government's emphasis on the need for more women on corporate boards in order to bring about gender equity. The UK government can therefore take any necessary action on firms that do not implement a gender balance in their decision making process, which will eventually put pressure on non-gender diversity firms and make them take steps in order not to be a target. Furthermore, the results support European Union (EU) action policies of ensuring that women are well represented in a firm's decision-making process. The performance of firms can serve as a link to complying with the EU regulation. Firms may inherently be complying with the EU and UK corporate governance code based on these empirical results.

However, the firm's ability to incorporate all the needed stakeholders especially women may also help win government support and gain access to critical resources such as government contracts and contacts, finance, and tax concessions that can help facilitate growth and improve on the firm's long-term financial performance (Ntim, 2013). Firms can also use this empirical 
result to make a business case about the importance of all stakeholders involved in achieving business success. Our results are consistent with stakeholder theory's predictions.

Third, Resource Dependence Theory suggests that firms exist so that they can critically use the resources available to maximise their financial performance (Pfeffer, 1978). Resources available to the firm include human capital, experience, independent suggestions and knowledge from either males or females (Haniffa and Cooke, 2002; Hillman and Dalziel, 2003). A diversified board can have an impact on the firm if it is able to link the firm to its external environment and its resources including skills, experiences of board members, prestige and legitimacy (Goodstein et al., 1994; Arnegger et al., 2013; Ntim, 2013). As women represent more than $50 \%$ of the world population, obviously they are major consumers and represent a group of talented people ${ }^{6}$. This means that the presence of women on the corporate board can help add new resources and improve the efficiency of the firm (Burke and Mattis, 2000).

Our empirical evidence provides positive support for resource dependence theory which suggests that gender diversity improves decision-making and helps align the organisation with its external environment and resources, thereby enhancing the firm's financial performance. These benefits occur because women are able to bring to the board different attributes, experiences and ideals that lead to a better appreciation of business complexities, which eventually improves the firm's earnings ability and corporate governance quality as well (Carter et al. 2003; Adams and Ferreira, 2009 Carter et al. 2010; Baranchuk and Dybig, 2009). When women are part of a firm's success, it will encourage the board to recruit more talented women, while other potential members will also be motivated and encouraged to apply for vacancies in the firm. Gender diversity can be used as a powerful tool for gender advocacy.

A number of researchers - Goodstein et al. (1994), Burges and Tharenou (2002), Dwyer et al. (2003), Roberson and Park (2007), Yang and Konrad (2011), and Ntim (2013) - argue that boardroom diversity is due to agency theory, stakeholding and resource dependence theories. This paper will follow the examples of these researchers and adopt the same theories. The three theories indicate that the representation of women on any corporate board has the propensity to increase the firm's financial performance. The next section gives a brief discussion of the financial crisis.

\subsection{The Financial Crisis - A Brief Review}

As the second objective of this research is centred on ascertaining the impact of women on UK financial institutions during the pre/post global financial crisis periods, there is the need to give a brief review of what transpired during the crisis era.

The financial crisis occurred in 2007/2008 when the mortgage market in the US collapsed and spread globally to other countries due to international trade and diversification of the portfolio for investors (Mizen, 2008). Prior to the crisis, the US economy experienced a high housing bubble, which later turned into a burst. The burst led to the fall of mortgage prices and in the end led to the collapse of large financial institutions (Mizen, 2008; Mintah and Schadewitz, 2015). Recent studies by Mintah (2015) on the financial crisis indicate that the mortgage business before the crisis was seen as one of the 'finest investments' one could ever have, as it was known to have given higher expected returns.

During the crisis, the financial sector in the UK was greatly hit and evidenced weaknesses in the corporate governance policies of these financial firms (Zagorchev and Gao 2015; Mintah

\footnotetext{
${ }^{6}$ https://www.bcg.com/documents/file56704.pdf, accessed on 06/02/16.
} 
and Schadewitz 2015). Studies by Siddiqui (2015) suggest that despite the substantial proliferation of corporate governance codes since 1978 and the empirical finding of a correspondingly large body of research, good governance failed to prevent the global financial crisis. Furthermore, financial firms such as Bradford \& Bingley, HBOS, Lloyds TSB, Northern Rock, Royal Bank of Scotland (RBS) all in UK, were heavily affected because their boards did not do enough in terms of supervision and monitoring of various activities in order to reduce the intensity of the crisis (Mintah \& Schadewitz, 2015).

The UK government bailed out these institutions from their financial difficulties, because there was issues with their risk management approach which ultimately affected their firm value and reduced their cash flow, (Krause and Tse 2016; Faff et al. 2011). The essence of board gender diversity is to bring divergent views and minimise any risk management in the firm ${ }^{7}$ (HM Treasury Committee Report, 2009, FRC, 2016).

The financial crisis forced the Bank of England (BoE), HM Treasury, Financial Conduct Authority (FCA) and the Financial Reporting Council (2014) to address corporate governance policies in UK financial firms. In addition, products and services such as mortgage securitisation, derivative trading, and short and long selling were scrutinised and regulated to avoid causing another crisis to the economy (BoE; HM Treasury, 2015; Mintah and Schadewitz, 2015). Regulating these products was in line with European Union (EU) reforms of financial firms in the wake of the financial crisis ${ }^{8}$.

The OECD, the Bank for International Settlements (Basel), the Committee on Banking Supervision, the Securities and Exchange Commissions (SEC), the World Bank and the IMF also supported corporate governance practices among countries and firms (Rezaee, 2007; Sun et al. 2011; Adams, 2009; Mintah and Schadewitz, 2015).

\subsection{Board Diversity and Firm Valuation: Prior Evidence and Hypothesis}

As per the research questions, this study will ascertain the impact of board gender diversity (BGD) on UK firms' financial value. Prior empirical evidence on board diversity and firm value provides mixed results. For example, current study by Zhong et al. (2017) on the role of board gender on the profitability of insider trading in Australia produced mixed results.

Prior research by certain authors (Perryman et al. 2016; Nguyen et al. 2015; Gyapong et al. 2015; Ntim, 2013; Adler, 2010; Campbell \& Mínguez-Vera, 2008; Carter et al. 2003) and other empirical literature reports that board diversity leads to higher performance. Recent studies by Perryman et al. (2016), using data from the US between 1992 and 2012, indicate that firms with greater gender diversity in their leadership were found to take fewer risks and have a higher firm performance when using Tobin's $Q$ as a measure of financial performance.

Galbreath (2016), using data from Australia's largest publicly traded firms' results, demonstrates that women on boards have a positive relationship with a firm's financial performance. Secondly, the results also show that representation of women on boards and financial performance are likely mediated by corporate social responsibility (CSR). Gyapong

\footnotetext{
7 The UK Government has an $82 \%$ stake in RBS through bailing out the bank with taxpayers' money.

8 http://www.bbc.co.uk/news/business-20811289, Accessed on 02/03/2016.
} 
et al. (2015) used hand-collected data from South African-listed firms from 2008-2013 and documented a positive and significant effect of both board gender and ethnic diversity on the value of a firm. They argued that a board with three or more women directors is expected to have an increase in the value of the firm where Tobin's Q served as a measure of financial performance. Another recent paper, by Nguyen et al. (2015), used a sample of 120 publicly listed companies in Vietnam covering a four-year period from 2008 to 2011. The result indicates that BGD appears to have a positive effect on the performance of the firm when using Tobin's Q measure. Further, Ntim (2013) found that board diversity is statistically significant and positively associated with firm value (Tobin's Q) during his research on the South Africa Stock Market.

Adler (2010) used 25 American-listed firms to find a positive correlation between employing a higher percentage of women in top management and firm value (Tobin's Q). This empirical study revealed that employing a portion of women on the board led to higher performance. Francoeur et al. (2008) examined whether the participation of women on the corporate board of a firm improves financial value in a sample of 230 Canadian-listed organisations from 2001 to 2004. Their findings indicated positive and significant returns in firms with a higher proportion of women officers. In 2008, a study conducted by Campbell and Mínguez-Vera (2008) revealed that gender diversity has a positive effect on the value of a firm using a panel data analysis of Spanish-listed firms.

Carter et al. (2003) reported a positive relationship between the presence of women on corporate boards and the value of the firm where Tobin's Q served as a measure of financial performance for Fortune 1000 firms. Additionally, Erhardt et al. (2003) examined the association between ethnic and gender representation on firm boards and suggested a positive relationship with the Tobin's Q of the firm when a sample of 127 large US firms was used.

By contrast, despite the positive relationship between board diversity and the financial performance of a firm, other researchers reported a negative relationship (Carter et al. 2010; Wang and Clift, 2009; Adams and Ferreira, 2009; Smith et al. 2006; Shrader et al. 1997; Goodstein et al. 1994).

Darmadi (2011) used data from the Indonesian Stock Exchange (ISE) to show that the presence of women in a boardroom has a negative impact on the firm's Tobin's Q. The research suggests that a female director appointment to an Indonesian board may be due to familial relationships rather than occupational expertise and professional experience. The research of Carter et al. (2010) failed to verify a significant relationship between gender and the ethnic diversity of corporate boards and financial performance when they used data from the S\&P 500 index. This means that the presence of women and ethnic diversity did not have any material impact on the S\&P-listed firms.

Studies by Adams and Ferreira (2009) reveal that the average effect of gender diversity on the performance of a firm is negative. This negative effect is due to firms with fewer takeover defences. They used a market-based measure of performance, a proxy for Tobin's Q. Rose (2007) used a sample of Danish-listed firms between 1998 and 2001 to study whether a female board influences the performance of a firm, but found no significant link between firm performance and female board representation. This empirical study indicates that female representation does not influence a firm's performance. Other empirical studies from Denmark by Smith et al. (2006) find a negative association between gender diversity on the corporate board and gross profits to sales using data from Danish firms, and also show no statistically significant association between board gender diversity (BGD) and accounting measures of 
financial performance. Farrell and Hersch (2005) used US data to investigate the effect of female directors on the board. Their research shows no evidence that an additional female on the board affects market returns to shareholders. Shrader et al. (1997) examined the association between female board members and a firm's financial value using a sample of 200 American firms. Their empirical result suggests a negative relationship between the percentage of women on the board and the firm's financial value. This means that the presence of women on the board may also have a financial cost implication to the firm, which can impact negatively on its value (Ntim, 2013).

Other empirical studies on gender diversity and the performance of a firm show an insignificant relationship. For example, studies by Marimuthu and Kolandaisamy (2009) between 2000 to 2006 in Malaysian firms indicate an insignificant relationship between gender diversity and the performance of the firm. Similarly, Rose (2007) examines whether female board representation influences firm value using a sample of Danish-listed organisations over the period 1998-2001. He finds no significant link between firm value and female board representation. Lastly, Zahra and Stanton (1988) used a sample of 95 American-listed organisations and found no significant relationship between board diversity and firm value. Their study was centred on board diversity and its impact on the firm's financial value.

However, given the mixed international evidence, we predict a positive and statistically significant association between board gender diversity and firm financial valuation. Therefore, our main hypothesis to be tested in this study is that:

Hypothesis 1: There is a positive and statistically significant association between board diversity on the basis of women and firm valuation as a measure of performance in UK financial institutions.

\subsection{Financial Crisis, Board Diversity and Firm Valuation: Prior Evidence and Hypothesis}

Empirical studies on the presence of women on a corporate board during the pre/post global financial crisis are very limited or scant. A recent study by Gyapong et al. (2015) shows that the financial crisis is associated with the propensity of firms to restructure their board along gender and ethnicity lines, and this study in South Africa used hand-collected data ranging from 2008 to 2013. The result of this research highlighted a positive relationship between the value of a firm and an increase in both gender and ethnicity diversity in the make-up of the board. This demonstrates that, in times of financial crisis, firms are more likely to increase the number of women and non-white directors on their corporate boards. The results also demonstrated that encountering a financial crisis decreases the likelihood of a firm reducing the number of its women and ethnic minority directors. The research by Gyapong et al. (2015) also clearly shows that the government policy on increasing gender and ethnic minority membership of boards in South African-listed firms was aimed at eradicating apartheid.

Additional study by Zagorchev and Gao (2015) during the financial crisis period, show that corporate governance affects financial institutions in the U.S. between 2002 and 2009 when using 41 governance index. Their findings indicate that better governance is negatively related to excessive risk-taking and positively related to the performance of U.S. financial institutions as measured by Tobin's Q. The second result show that better governance contributes to higher 
provisions and reserves for loan/asset losses of financial institutions. They excluded the financial crisis data in 2008.

Further research by Mintah (2016) on UK financial institutions reveals a positive and statistically significant association between the independent variable and Tobin's Q during the pre-crisis period but not during the post-crisis. The results were ascertained using Ordinary Least Square (OLS) and Random Effects (RE) regression estimator.

However, given the limited empirical evidence, we predict that financial crisis is associated with the tendency of UK financial firms to restructure their board along gender diversity. Therefore, the main hypothesis to be tested in this study is that:

Hypothesis 2: There is either a positive or a negative association between board gender diversity and firm valuation during the pre/post financial crisis periods.

\section{Research Method}

\subsection{Data and Sample Selection}

This gender research will use secondary data from DataStream (Thomson Reuters) and will look at the financial reports of 63 financial firms over a 12-year period ranging from December 2000 to December 2011. Independent variables, dependents and controls are all generated from DataStream. The use of annual reports is consistent with prior empirical studies (see, for example, Ntim et al. 2013; Mintah \& Schadewitz, 2015; Mintah, 2015; Gyapong et al. 2015). The data of the 63 financial firms extracted for 12 years generated 756 firm-year observations and is also consistent with prior studies by Mintah and Schadewitz (2015) and Mintah (2015). The financial firms used in this study are investment banking, insurance, mortgages, investment trust and banking services.

Panel data analysis will be used in this study as it gives: more degrees of freedom; less collinearity among variables; more cross-sectional and time-series variability; more efficiency; and accounts for more observable firm-level heterogeneity in individual-specific variables (see, for example, Gujarati, 2003; Ntim et al., 2013; Danso and Adomako, 2014; Mintah and Schadewitz, 2015; Mintah, 2015; Krause and Tse, 2016 ).

The breakdown of the firms used and other descriptions can be seen in table 1 .

[INSERT TABLE 1 HERE] 


\subsection{The Regression Design}

The data given would be tested using the following regression models, as indicated below:

Tobin's $Q_{i t}=\alpha_{0}+\alpha_{1}$ Gender Diversity ${ }_{i t}+\sum_{i=2}^{n} \alpha_{i}$ CONTROLS $_{i t}+\varepsilon_{i t}$,

where:

Tobin's $Q_{i t}$ for firm $i$ at time $t$, is the dependent variable used as a proxy for firm valuation. That is, Tobin's $\mathrm{Q}$ will represent and serve as a firm-based organisational valuation measure. The term $\alpha_{0}$ is constant; the independent variable is gender diversity (Gender), which represents women/females on the corporate board. The control variables are growth (GROWTH), leverage (LEV), size of the firm (SIZE) proxied by market capitalisation, whether the firm is classified a one of the big four financial institutions (BIG4), firm is dual-listed (DUAL), IND, and years of operation (YED). The controls will help reduce any potential omitted variable bias. The last term $\varepsilon_{i t}$ is the model error for firm $\mathrm{i}$ at time $\mathrm{t}$.

Dependent Variable Tobin's Q: Firm Value

Our measure of firm value is Tobin's Q, which is the ratio of total assets minus book value of equity plus market value of equity to total assets. The Tobin's Q-ratio is a risk-adjusted measure (Sila et al. 2016; Chung \& Pruitt, 1994, Beiner et al. 2006). Tobin's Q shows the financial estimation of the corporate governance structures of the firm, which capture the wealth of the firm from investors (outsiders) (Lindenberg and Rose, 1981; Mintah and Schadewitz, 2015; Mintah, 2015). The choice of Tobin's Q has been motivated, first, by prior empirical studies on gender diversity research all used Tobin's Q as a measure of firm's financial value (e.g., Sila et al. 2016; Perryman et al. 2016; Nguyen et al. 2015; Gyapong et al. 2015; Ntim, 2013; Adler, 2010; Carter et al. 2010; Wang and Clift, 2009; Marimuthu and Kolandaisamy, 2009; Campbell and Mínguez-Vera, 2008; Adams and Ferreira, 2009; Smith et al. 2006; Carter et al. 2003; Shrader et al. 1997; Goodstein et al. 1994; Zahra and Stanton, 1988; Krause and Tse, 2016). According to Siddiqui (2015) the use of Tobin's Q representing firm's financial value is considered as a more reliable performance measure in corporate governance literature than accounting value, as it reflects the long-term value of the firm.

Second, as the study examines the impact of board diversity on a firm's long-term value, the use of ROA and ROE - which are accounting measures of performance would not be suitable because they are short-term measures of performance while Tobin's Q measures long-term firm value (Bhagat and Black, 2002; Ntim 2013; Krause and Tse, 2016).

\section{(ii) The Control Variables}

Consistent with past studies (Carter et al. 2003, 2010; Black et al. 2006; Chenhall and Moers, 2007; Larker and Rusticus, 2008; Henry, 2008; Gompers et al. 2003; Klapper and Love, 2004; Haniffa and Hudaib, 2006; Guest, 2009; Ntim et al. 2013; Mintah and Schadewitz, 2015; Mintah, 2015; and Gyapong et al. 2015) we include a number of control variables for potential omitted variable bias. The use of these controls can impact on the financial outcome of a firm, as suggested by Chenhall and Moers (2007). First, organisations with greater (GROWTH) investment opportunities stand a chance of growing faster (Durnev and Kim, 2005). Any fastgrowing firm will receive higher valuations from investors and therefore expect sales growth to correlate positively with the value of the firm (Klapper and Love, 2004 and Ntim, 2013). In contrast, a firm with low growth opportunities is expected to have a negative firm value. 
Second, firms with high leverage (LEV) or debt can improve their firm valuation by reducing the ability of opportunistic managers to get access to free cash flow (Jensen, 1986; Guest, 2009; Ntim, 2013). A high leverage or debt should correlate positively with the firm value. Third, a larger firm size (SIZE) will receive a higher firm valuation than others (Botosan, 1997). A higher firm size is likely to have a positive association with its firm value (Beiner et al. 2006; Black et al. 2006). A small firm can attract external financing if it has good corporate governance mechanisms in place (Klapper and Love, 2004; Mintah and Schadewitz, 2015).

Fourth, the Big4 (BIG4) firms are PricewaterhouseCoopers, Deloitte \& Touche, Ernst \& Young and KPMG. However, other financial firms such as Grant Thornton and BDO Internal also use auditors. The Big4 controls $90 \%$ of the auditing business in terms of fees, revenue of clients and total assets (Beattie et al., 2003; Mintah \& Schadewitz, 2015; Mintah, 2015). A firm using a Big4 company can have either a positive or a negative correlation with its firm value. Fifth, a firm that is listed (DUAL) in more than one country is likely to have a better corporate governance structure as it has to conform to additional regulatory policies in the foreign exchange market (Haniffa \& Cooke, 2002; Black et al., 2006; Schadewitz, 2015; Mintah 2016). A dual-listed firm will have higher growth opportunities since it can access external capital (Klapper and Love, 2004; Mintah and Schadewitz, 2015; Mintah, 2016). Six, this research grouped the financial firms into five sectors, (IND), namely investment services, insurance, mortgages, investment trust and banking services (Mintah and Schadewitz, 2015; Mintah, 2015).

Finally, (YED) the number of years a firm does business can impact on the firm value. For example, a firm operating during a global financial crisis is expected to be down in terms of higher firm value (Mintah and Schadewitz, 2015). However, firms are known for performing better during a period of economic boom than during a period of recession (Turner Review, 2009; Walker Review, 2009; Mintah and Schadewitz, 2015; Mintah, 2015). Due to the conflicting theoretical expectations, the control variables can have either a negative or a positive correlation with the firm's financial valuation.

\section{[INSERT TABLE 2 HERE]}

\subsection{Descriptive Statistics}

Table 3 at the appendix presents full descriptive statistics of all variables used in conducting the empirical test. The descriptive statistics were calculated in order to ascertain the distribution of all the variables. All the figures generally suggest a wide variations similar to prior findings reported in the literature such as Beiner et al. (2006), Henry (2008), Guest (2009) and Ntim (2013). For instance, the minimum of Tobin's $Q$ is 0.00 , the maximum is 72.7 and the average is 10.4. The standard deviation value indicates wide variation consistent with prior empirical studies (Ntim, 2013). Also, since all dummy variables do not vary or change hence we will not report the mean, media or standard deviations for all dummy variables such as (IND, Big4, and DUAL) under the descriptive statistic section. 


\subsection{Testing for Multicollinearity}

Table 4 below presents the multicollinearity measure between the independent variables. Multicollinearity is an issue that happens in multivariate statistical analysis (Hair et al. 2006). According to Kline (1998), multicollinearity relates to a condition where there is a high correlation between independent variables in a regression model. Collinear independent variables provide the same information for the prediction of the independent variable. In testing for multicollinearity in this research, a Pearson Correlation matrix was examined. According to Hair et al. (1998), the correlation between any pair of variables should not be greater than 0.80 . Our test did not reveal any instances of multicollinearity between the independent variables (Hair et al., 1998; Kline, 1998).

\section{[INSERT TABLE 4 HERE]}

\section{Empirical Findings}

\subsection{Results}

The analysis will be divided into two parts. The first part will use the entire data from 2000 to 2011, whilst the second analysis will split the data into two: from 2000 to 2006 for the 'precrisis' period and from 2009 to 2011 for the 'post-crisis' period. This means that data for 2007 and 2008 will be excluded during the second analysis since the financial crisis happened in this era (see, for example, Mintah 2015; Mintah and Schadewitz, 2015).

[INSERT TABLE 5 HERE]

\subsection{Empirical Discussion of the Results - Table 5}

The analysis and discussion part of this research will follow the same pathway as used by Mintah and Schadewitz (2015) and Mintah (2016). Table 5 shows the Random Effects (RE) and the Fixed Effects (FE) estimation results on the presence of women and their impact on the firm's value (Tobin's Q). The essence of the two-regression models is to show consistency in the statistical results or outcome. The regression results show 756 observations. The $\mathrm{R}^{2}$ and the p-value are all statistically significant in the models.

The empirical results for the control variables indicate that, capital structure (LEV) and SIZE shows a positive but not significant effect on the firm's value (Tobin's Q) either using the Random Effects or Fixed Effects (FR) estimators. According to prior studies, firmsize (SIZE) attracts external financing if it has good corporate governance mechanisms in place (Klapper and Love 2004). The choice of employing a Big4 auditing firm as part of corporate scrutiny indicate no relationship with the firm's value.

These controls did not have a significant impact on the firm's Tobin's Q. However, GROWTH and a firm's dual-listing (DUAL) contributed positively and were statistically significant to the firm's financial value. This implies that firms with greater growth and investment opportunities stand a chance of increasing their financial value and firms that exist in more than one country 
will also have access to external capital, which will help to increase their financial performance. These results, using either the RE or FE regression estimation, are consistent with prior studies (e.g., Klapper \& Love, 2004; Haniffa \& Cooke, 2002).

The financial sector results indicate that Insurance (2) show a weak indication compared to Investment Banking sectors (1) in the statistical estimation. Additionally, Insurance (2), Mortgage (3) and Banking (5) all have a positive but insignificant relationship with the firm's value. This means that, empirically, these three financial sectors did not significantly affect the firm's financial performance. However, the empirical results in Table 5 indicate that Investment Trust (4) firms show a positive and statistically significant relationship with the firm's value (Tobin's Q) as a measure of financial performance. This implies that the establishment of investment trust firms where women serve on the corporate board has a positive impact and is statistically significant to the firm's financial performance.

\section{Board Gender Diversity Impact on the Firm's Value (Tobin's Q)}

Table 5 presents the empirical results emerging from this research when using either the Random Effect (RE) or Fixed Effects (FE) regression estimation. The use of these two estimations (RE \& FE) indicates the consistency and stability of the results. Our results provide significant evidence relating to the board gender diversity and firm value relationship. Empirically, the evidence states that having women (BGD) on the UK financial firms' corporate boards contributes positively and has a statistically significant relationship on their financial value (Tobin's Q) as a measure of financial performance. This means that an increase in gender mix may cause an increase in firm value. Women on the corporate board can influence decision-making, which can have an impact on the firm. When women are given the opportunity to work with their male counterparts, it will lead to a significant impact on the firm's financial performance. This empirical result is consistent with the second research debate by Carter et al. (2010) and Patterson (1997), which states that positive gender diversity among corporate directors results in better corporate governance mechanisms and helps enhance the performance of a firm.

The result supports our research motivations and empirically attests that the representation of women on UK corporate boards has a positive effect on the firm's value. In addition, the outcome of this empirical result supports the given hypothesis (H1) which states that there is a positive association between board gender diversity and the firm's values as a measure of financial performance. Finally, the results are consistent with earlier research and support the assertion that the representation of women on a corporate board can have a positive impact on the firm's financial value.

\section{[INSERT TABLE 6 HERE]}

\subsection{Empirical Discussion of the Results - Table 6}

The second analysis seeks to answer the last objective raised during the analysis and discussion section. This looks at the representation of women on the corporate boards of UK financial firms during the pre/post financial crisis. Table 6 shows that there are 441 and 189 observations for the pre/post global financial crisis respectively. The 2007 and 2008 data was dropped as the crisis happened in these two periods and generally firms do not perform well during an 
economic downturn. This means that the data covering that two-year period has been excluded. The $R^{2}$ for the pre/post periods are 0.145 and 0.199 respectively. The p-values for both periods are all statistically significant in the regression model.

The control variables accessed during the pre-crisis era indicate that GROWTH, SIZE and BIG4 did not influence the firms' value (Tobin's Q) during that period. This means that a firm's growth in terms of size and whether it uses a Big4 auditing firm did not translate into financial performance. However, capital structure (LEV) and dual-listing (DUAL) had a positive and statistically significant relationship to the firm's value. This implies that the firm's access to leverage and its ability to be listed in more than one country influenced its corporate governance structure and had a positive and significant impact on its financial value.

The control variables in terms of the post-crisis period show that the use of GROWTH and LEV as control variables did not also influence the firm's financial performance. Additionally, SIZE and BIG4 show a negative but significant relevance to the firm's value during the postcrisis period. In contrast, the firm's dual-listing (Dual) had a positive and statistically significant relationship on the firm's value. This is consistent with the pre-crisis results for (DUAL) and reiterates that when firms are dual-listed it can have an influence on their profitability.

In terms of the financial sectors, the empirical evidence gathered indicates that all the sectors during the pre/post financial crisis era had a positive influence on the firm's financial performance. Predominantly, there was a positive and statistically significant relationship between financial services such as mortgage and investment trust and the firm's value (Tobin's Q) as a measure of financial performance even during the pre/post financial crisis era. This means that gender-diverse boards in these firms enhanced their financial performance.

\section{Pre-Financial Crisis Analysis}

The empirical results ascertained during the pre-financial crisis period indicate that gender diversity that is, the presence of women on UK financial firms' corporate boards has a positive and statistically significant relationship to the firm's value (Tobin's Q) as a measure of performance. A higher presence of females on the corporate board leads to a higher firm value. The presence of women in these firms was able to ensure that appropriate monitoring and oversight procedures were followed, thereby yielding good financial performance. The result could imply that the experience, skills and knowledge of the women were vital for the success of these firms. Furthermore, the pre-crisis period results reveal that the participation of women on the board made the firm strong in terms of financial performance. As suggested by Julizaerma and Sori (2012), women have the ability to manage any firm due to their characteristics, which are believed to be emotional, meticulous and fussy in any decisionmaking process. These characteristics made investors and shareholders respond positively to the firm's financial value. Empirically supporting this analysis is research by Choi et al. (2004), which reports a positive performance of Korean firms during the Asian financial crisis in 1997. As indicated by Lindenberg and Rose (1981), a firm's financial performance is an indication of its corporate governance valuation from the perspective of investors or shareholders. This means that investors and shareholders have confidence in female representation on the corporate board as their presence translated into significant financial gains for the firm. This result is also consistent with the given hypothesis (H2) which suggests that there could be a positive association between board gender diversity and firm valuation during the pre-financial crisis period. 


\section{Post-Financial Crisis Analysis}

The relationship between a firm's value and gender diversity in the post-crisis period as shown in Table 6, points to a positive coefficient. The p-value, however, indicates that the relationship is insignificant. This means that there is a positive but insignificant relationship between firm value and GENDER mix during the post-crisis period. A reasonable explanation may be that, even though the financial crisis was over from 2009-2011, the entire UK economy was still experiencing an economic downturn and financial firms were no exception, irrespective of whether there was female representation on any corporate board. Another interesting view surrounding the post-financial crisis results is that the harsh macro-economic conditions after the crisis overshadowed the importance of women on the corporate board (Review of HM Treasury's response to the financial crisis report, 2012) ${ }^{9}$. This has nothing to do with their competence but to uncontrollable systemic factors which are beyond their control.

Additionally, after the financial crisis, the fear and panic that erupted throughout the entire economy stopped investors investing in any firm, as they became very cautious and risk averse. The lack of confidence in the entire economy affected firms' financial performance, which resulted in the UK government urging investors and other entrepreneurs to start investing in the economy. The government also injected liquidity into the entire financial market ${ }^{10}$.

Despite all the brouhaha that surrounded the entire economy during the post-crisis period (2009-2011), the relationship between the firm's value and GENDER was positive, even though not statistically significant. After the financial crisis period, shareholders and investors still felt that financial firms' internal corporate governance structures were no different from any other sectors. All things being equal, any weak or negative perspective from investors would have a major consequence on a firm's value. A recent study by Gyapong et al. (2015) states that firms should restructure their boards along gender lines during and after a financial crisis period. The empirical evidence pertaining to the pre/post financial crisis periods supports the second hypothesis (H2), which states that there is either a positive or a negative association between board gender diversity and firm valuation during the pre/post financial crisis periods.

\subsection{Robustness Checks}

In checking the robustness of the results, Random Effects (RE) and Fixed Effects (FE) estimators were conducted according to the Durbin-Wu-Hausman exogeneity test. The two estimators show that each variable, its coefficient and its significant level did not change greatly with either the RE or the FE estimation. Therefore, we can conclude that the results were stable and consistent across a number of proxies and that there were no differences between the results of each estimator. The results remain unchanged after performing various robustness checks. Furthermore, the robustness or sensitivity analyses suggested that the results

\footnotetext{
${ }^{9} \mathrm{http}: / /$ www.bbc.co.uk/news/business-20811289, accessed 16/01/17.

${ }_{10} \mathrm{http}: / /$ news.bbc.co.uk/1/hi/business/7521250.stm, http://news.bbc.co.uk/1/hi/business/7666570.stm, accessed $20 / 03 / 2017$
} 
were stable across a number of proxies using either the Random Effects or the Fixed Effects results in our analysis (Mintah, 2015; Zagorchev and Gao, 2015).

\subsection{Controlling for Endogeneity}

Endogeneity issue occurs when the independent variable is correlated with the error term. To control problems that may arise as a result of omitted variables, we first implement DurbinWu-Hausman's exogeneity test to ascertain the relationship between board gender diversity and firm value and whether an endogenous association exists between the variables (see, for example, Beiner et al., 2006 and Ntim, 2013). This was carried out by re-estimating all the regression with lagged values, and our results were robust and significant to different types of potential endogeneity problems. This research follows similar endogeneity studies by Fich and Shivdasani (2006), Krishnan et al. (2011), Danso and Adomako (2014), Ntim (2013), Mintah and Schadewitz (2015), and Zagorchev and Gao (2015).

Although this research has addressed endogeneity problems, by estimating a lagged value on each variable, we admit that it is extremely difficult to eliminate all potential endogenous associations, as also suggested by prior studies by Ntim (2013) and Mintah and Schadewitz (2015).

\section{Summary and Conclusions}

Based on the research motivations and the empirical results ascertained, it has been proven beyond every reasonable doubt that the appointment of women to the corporate board is vital to a firm's success. The appointment of women to any corporate board should be carried out with the motive that their presence would enhance the firm's financial value and not as a symbolic gesture to them. The presence of women on any corporate board should focus on what they will be able to add to the performance of the board and not be a sign of tokenism.

Despite prior empirical studies on gender diversity, no studies have explored how the presence of women on the corporate boards of UK financial institutions influences a firm's financial value. This current study constitutes one of the first attempts to empirically ascertain board gender diversity and firm value in UK financial institutions and also during the pre/post financial crisis era. The outcome of this empirical research shows that the presence of women on the corporate boards of UK financial institutions has a positive and statistically significant relationship to the firm's value. Our evidence reveals that before the financial crisis era (20002006) the presence of women on the corporate board also had a positive and statistically significant impact on the firm's value. This means that women contributed significantly to the firm's value. However, after the financial crisis period, the presence of women on the board caused a positive impact but one that was not statistically significant to the firm's value. A reasonable explanation may be that, even though the financial crisis was over from 2009-2011, the entire UK economy was still experiencing an economic downturn and financial firms were no exception, irrespective of whether there was female representation on any corporate board. Another interesting view surrounding the post-financial crisis results is that the harsh macroeconomic conditions after the crisis overshadowed the importance of women on the corporate board $^{11}$ (Review of HM Treasury's response to the financial crisis report, 2012). This has

${ }^{11}$ http://www.bbc.co.uk/news/business-20811289, accessed 16/01/17. 
nothing to do with their competence but to uncontrollable systemic factors which are beyond their control.

Our results provide significant evidence concerning the board gender diversity and firm value relationship and contribute to the literature in a number of ways. First, the evidence of a positive effect of board gender diversity on firm valuation provides support for the recommendations of various corporate governance reforms in the UK, European Commission quotas about the percentage of women on any board and, finally, support from lobbying groups such as Women Corporate Directors wishing to see women being represented on any corporate board. The results reiterate the need for women to be part of any corporate decision-making process and reinforce the belief that women have the same prowess as men in achieving a firm's financial success.

Second, the paper provides practical implications for governments, policy-makers and regulatory authorities by indicating the importance of women to corporate success. This research is also of interest to investors and companies by highlighting the significant relationship between gender diversity and firm values among UK financial firm (Siddiqui, 2015). The nomination committee should ensure that there is a regular check on the level of women or gender compliance in order to ensure that they improve board standards and enhance firm value. Third, another practical implication about this research is to help countries considering or contemplating pursuing board gender diversity reforms. Specifically, countries such as Malaysia, Australia, New Zealand, and all members in the European Union, aim to improve gender representation in their corporate boards, (Ntim 2013). Fourth, our findings are consistent with agency, stakeholder and resource dependence theories, which suggest that gender diversity enhances board monitoring and brings a diversity of ideas, new perspective, experience and business knowledge to the decision-making process in boardrooms, thereby improving the firm's financial valuation. Overall, the results will help to fill any missing gap in gender diversity and firm value in UK financial institutions.

Regardless of the contributions made by this paper, this piece of work has some research limitations. Due to data constraints, we were unable to include the women's educational background information and any future studies should look into this. Furthermore, future studies could look at how gender diversity in the UK influences other fields, especially in the educational sector.

\section{Reference:}

Adams, R. B. \& D. Ferreira (2009), 'Women in the boardroom and their impact on governance and performance', Journal of Financial Economics, Volume 94, page 291-309.

Adler, R. D. (2010), Women in the executive suite correlate to high profits. Glass Ceiling Research. Available at: http://www.women2top.net/download/home/adler_web.pdf. Accessed 01 March 2016.

Arnegger, M., Hofmann, C., Pull, K., \& Vetter, K. (2013), Firm size and board diversity. Journal of Management and Governance. (Forthcoming). 
Bank of England (BoE) Prudential Regulation on Banks,

http://www.bankofengland.co.uk/PRA/Pages/default.aspx, accessed 2 January 2016.

Baranchuk, N. \& Dybvig, P. H. (2009), Consensus in Diverse Corporate Boards. Review of Financial Studies, 22(2), 715-747.

Basel Committee on Banking Supervision (2014), Enhancing Corporate Governance for Banking Organization, Bank for International Settlement, Basel III, http://www.bis.org/publ/bcbs176.pdf.

Beiner, S., Drobetz, W., Markus, M. \& Zimmermann, H. (2006), 'An Integrated Framework of Corporate Governance and Firm Valuation', European Financial Management, Volume 12, No. 2, page 249-283.

Berle, A.A. \& Means, G.C. (1932), The Modern Corporation and Private Property. New York: Macmillan.

Bhagat, S. \& Black, B. (2002), The non-correlation between board independence and long term firm performance, Journal of Corporation Law 27, 231-274.

Black, B. S., Jang, H. \& Kim, W. (2006), 'Does Corporate Governance Predict Firm's Market Values? Evidence from Korea, Journal of Law Economics and Organization, Volume 22, No. 2, page 366-413.

Blair, M. M. (1995), Ownership and Control: Rethinking Corporate Governance for the Twenty-First Century, The Brookings Institution, Washington, USA.

Botosan, C. A. (1997), 'Disclosure Level and the Cost of Equity Capital', Accounting Review, Volume 72, No. 3, page 323-350.

Brancato, C. K., \& Patterson, D. J. (1999), 'Board diversity in US Corporations; Best Practices for broadening the profile of corporate boards' Research Report 1230-99-RR, the conference board.

Burges, Z., \& Tharenou, P. (2002), Women board of directors: Characteristics of the few', Journal of Business Ethics, 37, 39-49.

Burke, R., \& Mattis, M. (2000), Women on Corporate Boards of Directors: International Challenges and Opportunities. Kluwer, Dordrecht, The Netherlands, page 118-125. 2000.

Campbell, K. \& A. Minguez-Vera (2008), 'Gender diversity in the boardroom and firm financial performance', Journal of Business Ethics, Volume 83, page 435-451.

Carter, D. A., B.J. Simkins \& W.G., Simpson (2003), 'Corporate governance, board diversity and firm value', Financial Review, Volume38, page33-53.

Carter, D. A., F. D'Souza., B.J. Simkins., \& W.G. Simpson (2010), 'The gender and ethnic diversity of US boards and board committees and firm financial performance', Corporate Governance: An International Review, Volume18, No. 5, page 396-414. 
Catalyst, (2011), The Bottom Line: Corporate Performance and Women's Representation on Boards (2004-2008). Catalyst.

Chenhall, R. H. \& Moers, F. (2007), 'The Issue of Endogeneity within Theory-Based, Quantitative Management Accounting Research', European Accounting Review, Volume 16, No. 1, page 173-195.

Choi, J. H.; Jeon, K. \& Prk, J. (2004), "The Role of Audit Committee in Decreasing Earning Management: Korean Evidence." International Journal of Accounting, Auditing and Performance Evaluation, Volume 1, No. (1), (2004), 37-60.

Chung, K. H. \& Pruitt, S. W. (1994), ‘A Simple Approximation of Tobin's Q’, Financial Management, Volume 23, No. 3, page 70-74.

Cotter, D. A., J.M. Hermsen, S. Ovadia, \& R. Vanneman (2001), 'The Glass Ceiling Effect', Social Forces, Volume 80, No.2, page 655-682.

Danso, A; \& S; Adomako (2014), The financial behavior of firms and financial crisis, Managerial Finance, Volume 40, No.12, 2014; Emerald Group Publishing Limited.

Darmadi, S., (2011), Board diversity and firm performance: The Indonesian evidence; Corporate Ownership and Control, Volume. 1, No. 9 (2011): page 524-539.

Doldor, E., Vinnicombe, S., Gaughan, M., \& Sealy, R., (2012), Gender Diversity on Boards: The Appointment Process and the Role of Executive Search Firms; International Centre for Women Leaders Canfield School of Management, Canfield University.

Durnev, A. \& Kim, E. H. (2005), 'To Steal or Not to Steal: Firm Attributes, Legal Environment, and Valuation', Journal of Finance, Volume LX, No. 3, page 1461-1493.

Dwyer, S., Richard, O. C., \& Chadwick, K. (2003), Gender diversity in management and firm financial performance; Journal Business Research, 56, 1009-1019.

Erhardt, N. L., Werbel, J. D., \& Shrader, C. B. (2003), Board of director diversity and firm financial performance; Corporate Governance: An International Review, 11, 102-111.

Faff, R., Hallahan, T., \& McKenzie, M. (2011), "Women and risk tolerance in an aging world", International Journal of Accounting \& Information Management, Vol. 19 Issue: 2, 2011, pp.100-117, Emerald Group Publishing Limited, 1834-7649.DOI $10.1108 / 18347641111136427$.

Farrell, K. A., \& Hersch, P. L. (2005), Additions to corporate boards: The effect of gender; Journal of Corporate Finance, 11, 85-106.

Fich, E., \& A. Shivdasani (2006), 'Are busy boards effective monitors', Journal of Finance, Volume 61, page 689-724.

Financial Reporting Council (2014), https://www.frc.org.uk/OurWork/Publications/Corporate-Governance/Guidance-on-Audit-Committees-September2014.aspx. 
Finegold, D., Benson, G.S., \& Hecht, D., (2007), Corporate boards and company performance: review of research in light of recent reforms. Corporate Governance; An International Review $15,865-878$.

Francoeur, C., Labelle, R., \& Sinclair-Desgagne', B. (2008), Gender diversity in corporate governance and top management; Journal of Business Ethics, 81, 83-95.

Galbreath, J. (2016), Is Board Gender Diversity Linked to Financial Performance? The Mediating Mechanism of CSR; Business \& Society, 1-27; bas.sagepub.com.

Global Corporate Governance Principles: Revised (2009), International Corporate Governance Network, ICGN, 2009.

Gompers, P., Ishii, J. \& Metrick, A. (2003), 'Corporate Governance and Equity Prices', Quarterly Journal of Economics, Volume 118, page 107-155.

Goodstein, J., Gautum, M. E., \& Boeker, W. (1994), The effect of board size and diversity on strategic change; Strategic Management Journal, 15, 241250.

Guest, P. M. (2009), 'The Impact of Board Size on Firm Performance: Evidence from the UK', The European Journal of Finance, Volume 15, No. 4, page 385-404.

Gujarati, D. N. (2003), Basic econometrics. New York, USA: McGraw-Hill.

Gyapong, E, Monem, R. M; \& F, Hu (2015), Do Women and Ethnic Minority Directors Influence Firm Value? Evidence from post-Apartheid South Africa; Journal of Business Finance \& Accounting, 2015.

Hair, J. F. J., Anderson, R. E. Tatham, R. L \& Black, W. C. (1998), Multivariate Data Analysis. New York: Macmillan.

Hair, J. F. J., Anderson, R. E. Tatham, R. L \& Black, W. C. (2006), Multivariate Data Analysis with Readings. New York: Macmillan.

Haniffa, R. \& Hudaib, M. (2006), 'Corporate Governance Structure and Performance of Malaysian Listed Companies', Journal of Business, Finance and Accounting, Volume 33, No. $7 \& 8$, page 1034-1062.

Haniffa, R. M. \& Cooke, T. E. (2002), 'Culture, Corporate Governance and Disclosure in Malaysian Corporations', Abacus, Volume 38, No. 3, page 317-349.

Hausman, J. A. (1978), Specification tests in econometrics. Econometrica, Volume 46, 1251 1271.

Henry, D. (2008), 'Corporate Governance Structure and the Valuation of Australian Firms: Is there Value in Ticking the Boxes', Journal of Business Finance and Accounting, Volume 35, No. $7 \& 8$, page $912-942$.

Higgs, D. (2003), Review of the Role and Effectiveness of Non-Executive Directors. London: UK Department of Trade and Industry. 
Hill, C.W.L. \& Jones, T.M. (1992), 'Stakeholder-Agency Theory', Journal of Management Studies, Volume 29, No. 2: 131-54.

Hillman, A. J., J.A.A. Cannella, \& I.C. Harris (2002), 'Women and Racial Minorities in the Boardroom. How do directors differ?', Journal of Management, Volume 28. Page 747-763.

Hillman, A.J., \& Dalziel, T., (2003), Boards of directors and firm performance: integrating agency and resource dependence perspectives; Academy of Management Review. 28, 383-396.

HM Treasury (2015), https://www.gov.uk/government/publications; accessed 10 January 2016.

Jensen, M. C. (2001), 'Value Maximisation, Stakeholder Theory and the Corporate Objective Function', European Financial Management, Volume 7, No. 3, page 297-317.

Jensen, M. C. (2002), 'Value Maximisation, Stakeholder Theory, and the Corporate Objective Function', Business Ethics Quarterly, Volume 12, No. 2, page 235-247.

Jensen, M. C. \& Meckling, W. H. (1976), 'Theory of the Firm: Managerial Behaviour, Agency costs and Ownership Structure', Journal of Financial Economics, Volume 3, page 305-360.

Jensen, M.C., (1986), Agency costs of free cash flow, corporate finance, and takeovers. American Economic Review, 76, 323-329.

Johnston, D., \& Malina, M. A. (2008), Managing sexual orientation diversity: The impact on firm value; Group and Organization Management, 33, 602-625.

Julizaerma M.K. \& Z, M. Sori (2012), Gender Diversity in the Boardroom and Firm Performance of Malaysian Public Listed Companies, International Congress on Interdisciplinary Business and Social Science. Procedia - Social and Behavioral Sciences 65 (2012) $1077-1085$.

Kanter, R.M., (1977), Men and Women of the Corporation. Basic Books, New York, NY.

Khosa, A. (2017), Independent directors and firm value of group-affiliated firms. International Journal of Accounting \& Information Management, Vol. 25 No.2, 2017, pp.217-236, Emerald Publishing Limited, 1834-7649.

Klapper, L. F. \& Love, I. (2004), 'Corporate Governance, Investor Protection, and Performance in Emerging Markets', Journal of Corporate Finance, Volume 10, page703-728.

Kline, R. B. (1998), Principles and Practices of Structural Equation Modelling. New York, Guilford Press.

Konek \& S.L. Kitch (Eds.), Women and careers: Issues and challenges (page 206-233). Thousand Oaks, CA: Sage.

Konek, C. W. (1994), Leadership or empowerment? Reframing our questions. In C. W. Kramer, V. W., A.M. Konrad, S. Erkut, \& M.J. Hooper (2007), 'Critical mass on corporate boards: why three or more women enhance governance', Volume 31, No.2, page19-22. 
Krause, A. T., and Tse, Y, (2016), "Risk management and firm value: recent theory and evidence", International Journal of Accounting and Information Management, Vol. 24 Issue: 1, pp.56-81. Emerald Group Publishing Limited.

Krishnan, C. N. V.; Vladimir, I.; Masulis, R., \& Singh, A. (2011), Venture Capital Reputations, Post-IPO Performance, and Corporate Governance. Journal of Financial and Quantitative Analysis, Vol. 46(5): 1295-1333.

Larker, D. F. \& Rusticus, T. O. (2008), 'On the Use of Instrumental Variables in Accounting Research', Working Paper, SSRN, available at: http://papers.ssrn.com/sol3/papers.cfm? accessed on 30 December 2015.

Levine, R. (2003), The Corporate Governance of Banks- A Concise Discussion of Concepts and Evidence July 21 (2003).

Lim, S., Matolcsy, Z. \& Chow, D. (2007), 'The Association between Board Composition and Different Types of Voluntary Disclosure', European Accounting Review, Volume 16, No. 3, page 555-583.

Lincoln, A., \& Adedoyin, O. (2012), Corporate governance and gender diversity in Nigerian boardrooms. World Academy of Science, Engineering and Technology, 71, 1853-1859.

Lindenberg, E. B. \& Ross, S. A. (1981), ‘Tobin's q Ratio and Industrial Organization', Journal of Business, Volume 54, page 1-33.

Lord Davies Report (2011), Women on boards, available at; www.gov.uk.

Low, C. M. D; Roberts, H. \& Whiting, H. R. (2015), Board gender diversity and firm performance; Empirical evidence from Hong Kong, South Korea, Malaysia and Singapore, Pacific-Basin Finance Journal, Volume 35 (2015), page 381-401.

March, J. and Simon, J. H. (1958), Business review; Organisation, Wiley, USA.

Marimuthu, M., \& Kolandaisamy, I., (2009), Ethnic and gender diversity in boards of directors and their relevance to financial performance of Malaysian companies; Journal of Sustainable Development. Volume 2, page 139-148.

McLeod, P. L., \& Lobel, S. A. (1992), The effect of ethnic diversity on idea generation in small groups. Academy of Management Annual Meeting Best Papers Proceedings, Volume 2, page 227-231.

Mintah, A. P. (2015), The Nomination Committee and Firm Performance; An Empirical Investigation of UK Financial Institutions during the pre/post financial crisis, Corporate Board; Role, Duties \& Compositions, Volume 11, Issue 3, 2015.

Mintah, A.P. \& Schadewitz, H. (2015), Audit Committee Adoption and Firm Value: Evidence from UK Financial Institutions, Working Paper. 
Mizen, P. (2008), The Credit Crunch of 2007-2008; A Discussion of the Background, Market Reactions and Policy Responses, Federal Reserve Bank of St. Louis Review, page 531-607.

Nguyen, T; Locke, S. \& Reddy, K. (2015), Does boardroom gender diversity matter? Evidence from a transitional economy, International Review of Economics and Finance; Volume 37 (2015), page 184-202.

Ntim (2013), 'Board Diversity and Organizational Valuation: Unravelling the effects of Ethnicity and Gender', Journal of Management Governance.

OECD, (2004), OECD Principles of Corporate Governance, 2nd Edition, Organization for Economic Co-operation and Development (OECD), Paris, France.

Perryman, A. A, Fernando, G. D \& A, Tripathy (2016), Do gender difference persist? An examination of gender diversity on firm performance, risk, and executive compensation, Journal of Business Research, Volume 69 (2016) 579-586.

Pfeffer, J., \& G.R. Salancik. (1978), 'The external control of organizations: A Resource dependence perspective', New York: Harper \& Row.

Rezaee, Z. (2007), Corporate Governance Post-Sarbanes-Oxley. Hoboken, NJ: John Wiley \& Sons.

Roberson, Q. M., \& Park, H. J. (2007), Examining the link between diversity and firm performance; The effects of diversity reputation and leader racial diversity. Group and Organization Management, 32, 548-568.

Rose, C. (2007), 'Does female board representation influence firm performance? The Danish evidence', Corporate Governance: An International Review, Volume 15, page 404-413.

Shrader, C., Blackburn, V., \& Iles, P. (1997), Women in management and firm financial performance: An exploratory study; Journal of Managerial Issues, 9, 355-372.

Siddiqui, S.S. (2015), 'The association between corporate governance and Firm performance a meta-analysis", International Journal of Accounting and Information Management, Vol. 23 No. 3, 2015, pp. 218-237, Emerald Group Publishing Limited 1834-7649, DOI 10.1108/IJAIM-04-2014-0023.

Sila, V; Gonzalez, A, \& J. Hagendorff (2016), Women on board: Does boardroom gender diversity affect firm risk? Journal of Corporate Finance 36 (2016) 26-53.

Smith, N., V. Smith, \& M. Verner (2006), Do women in top management affect firm performance? A panel study of 2500 Danish firms', International Journal of Productivity and Performance Management, Volume 55, page 569-593.

Sun, W., Stewart, J., \& Pollard, D. (2011), Rethinking corporate governance lessons from the global financial crisis, International Perspectives. ISBN 978-1-107-00187-9, Cambridge University Press 2011. 
Terjesen, S., R. Sealy, and V., Singh, (2009), 'Women directors on corporate boards: A review and research agenda', Corporate Governance: an International Review, 17:320-337.

Triana, M. C., T.L. Miller, \& T.M Trezebiatowski (2014), 'The Double-edged nature of board gender diversity: Diversity, firm performance, and the power of women directors as predictors of strategic change', Organization Science, Volume 5, No.2, page 609-632.

Tyson, L (2003), The Tyson Report on the Recruitment and Development of Non-Executive Directors. London: London Business School.

Walker Review (2009), A Review of Corporate Governance in UK Banks and Other Financial Industry entities, HM Treasury, London, UK.

Wang, Y., \& Clift, B., (2009), Is there a "business case" for board diversity? Pacific Accounting Review. Volume 21, page 88-103.

Wittenberg-Cox, A. and Maitland, A. (2008), Why Women Mean Business: Understanding the Emergence of Our Next Economic Revolution, John Wiley and Sons, London.

Yang, Y., \& Konrad, A. M. (2011), Understanding diversity management practices: Implications of institutional theory and resource-based theory. Group and Organization Management, Volume 36, page 6-38.

Yermack, D. (1996), 'Higher Market Valuation of Companies with a Small Board of Directors', Journal of Financial Economics, Volume 40, page 185-211.

Yi, A., (2011), Mind the Gap: Half of Asia's Boards Have no Women, A Risky Position for Governance and Growth. The Korn/Ferry Institute.

Zagorchev, A. \& Gao L. (2015), Corporate governance and performance of financial institutions, Journal of Economics and Business.

Zahra, S. A., \& Stanton, W. W. (1988), The implication of board of directors' composition for corporate strategy and value. International Journal of Management, 5, 229-236.

Zhong, T., Faff, R., Hodgson, A., \& Yao, J. Lee (2014), The role of board gender on the profitability on insider trading. International Journal of Accounting \& Information Management, Vol. 22 No.3, 2014, pp.180-193, Emerald Publishing Limited, 1834-7649.

Zimmer, L., (1988), Tokenism and women in the workplace: the limits of gender-neutral theory. Social Problem, Volume 35, page 64-77. 


\section{Appendix}

Table 1: Classification and Representation of Variables

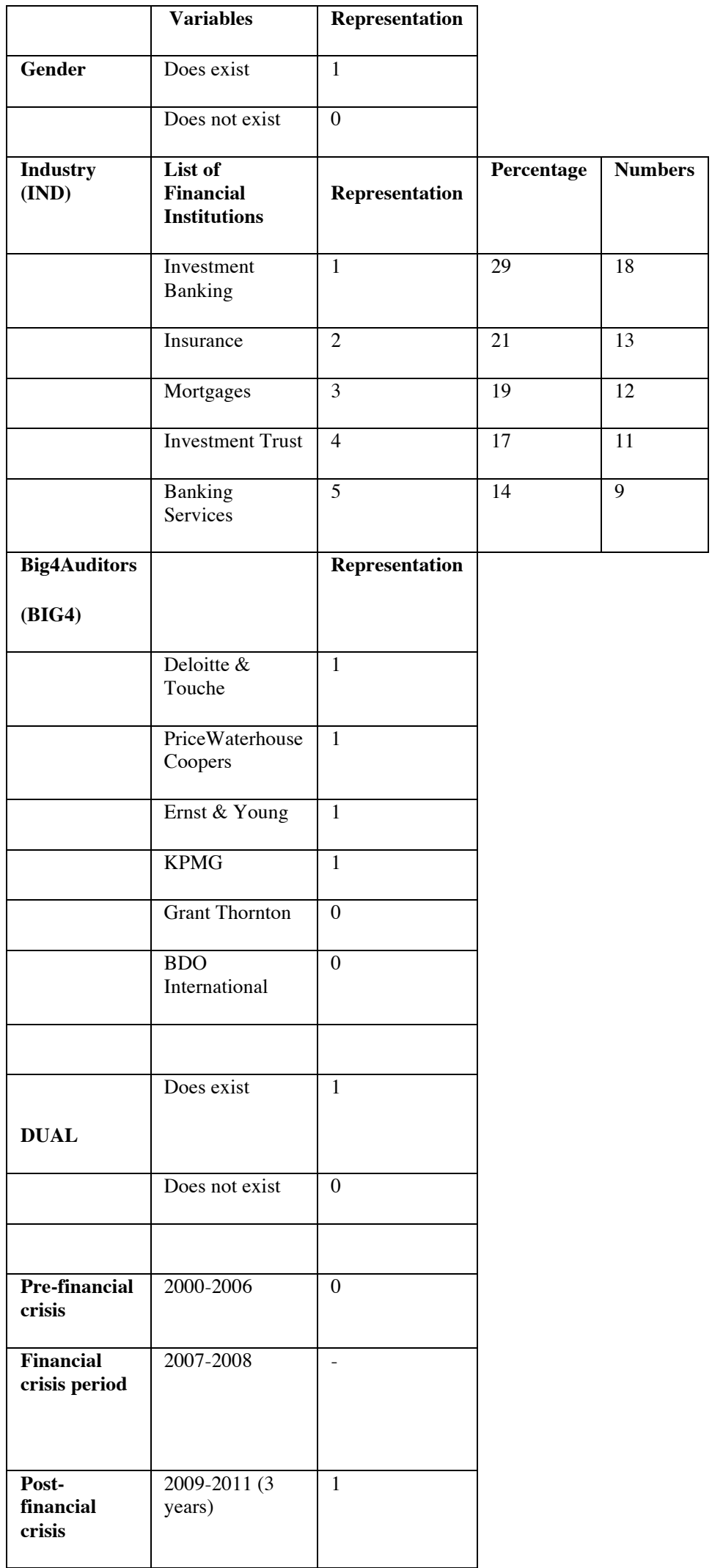

(Source: Mintah and Schadewitz, 2015; Mintah, 2015) 
Table 2: Below gives a description of each of the variables.

\begin{tabular}{|c|c|}
\hline $\begin{array}{l}\text { Dependent } \\
\text { Variables }\end{array}$ & \\
\hline Tobin's $Q$ & $\begin{array}{l}\text { The ratio of total assets minus book value of equity plus market } \\
\text { value of equity to total assets. }\end{array}$ \\
\hline Independer & ble: \\
\hline GENDER & $\begin{array}{l}\text { Female representation on the corporate board has a dummy } \\
\text { variable equal to " } 1 \text { " otherwise } 0 . \text { ' }\end{array}$ \\
\hline Control I & \\
\hline GROWTH & $\begin{array}{l}\text { Growth is the percentage of the current year's sales minus } \\
\text { previous year's sales scaled by the previous year's sales. }\end{array}$ \\
\hline$L E V$ & Leverage is the percentage of total debt to total assets. \\
\hline SIZE & Firm Size is the natural Log of total assets. \\
\hline BIG4 & $\begin{array}{l}\text { A Dummy variable equal to " } 1 \text { " if a firm is audited by a Big } 4 \\
\text { otherwise " } 0 \text { " }\end{array}$ \\
\hline DUAL & $\begin{array}{l}\text { A Dummy variable equal to " } 1 \text { " if a firm is dual-listing otherwise } \\
\text { " } 0 \text { " }\end{array}$ \\
\hline IND & $\begin{array}{l}\text { Classifies into 5-sectors namely: 1. Investment services } 2 . \\
\text { Insurance 3.Mortgages 4.Investment Trust 5. Banking Services }\end{array}$ \\
\hline Year & $\begin{array}{l}\text { The year's cover from } 2000 \text { to } 2011 \text {. They are represented as } \\
\text { follows: 2000;2001;2002;2003;2004; 2005;2006; 2007; 2008; } \\
\text { 2009; 2010;2011. }\end{array}$ \\
\hline
\end{tabular}




\begin{tabular}{lcccccc}
\hline & Count & Mean & Median & SD & Min & Max \\
\hline Tobin's Q & 756 & 10.461 & 5.881 & 13.066 & 0.000 & 72.712 \\
GENDER & 756 & & & & 0 & 1 \\
Control & & & & & & \\
LEV & 756 & 2.027 & 1.231 & 2.572 & 0.000 & 17.617 \\
SIZE & 756 & 9.911 & 13.143 & 6.214 & 0.073 & 19.709 \\
Big4 & 756 & & & & 0 & 1 \\
DUAL & 756 & & & & 0 & 1 \\
IND & 756 & & & & 1 & 5 \\
\hline
\end{tabular}

Notes: This table presents the result of the descriptive statistics for all the variables. It shows 756 numbers of observations for all the variables with their Mean, Median, Standard Deviations, Minimum and Maximum. Since all dummy variables do not vary/change hence we will not report Mean, Media or Standard Deviations for all dummy variables such as (IND, Big4, and DUAL) in this paper. The variables are defined as follows: Tobin's Q is the ratio of total assets minus book value of equity plus market value of equity to total assets (Chung and Pruitt, 1994); (GENDER)-Here represent women on the corporate board. (GROWTH): is defined as the ratio of sales growth to total assets growth (Beiner et al., 2006). (LEV) is defined as the Percentage of total debt to total assets, (Modigliani and Miller 1958). (SIZE): Is defined as the natural log of total assets (Botosan 1997). BIG4-are (PricewaterhouseCoopers, Deloitte \& Touche, Ernst\& Young and KPMG); (DUAL): Is defined as a situation where the firm is cross-listed in other countries (Haniffa and Cooke 2002; Black et al., 2006). Industry (IND): classifies into 1. Investment services 2. Insurance 3.Mortgages 4.Investment Trust 5. Banking Services. 
Table 4: Pearson Correlation matrix

\begin{tabular}{|c|c|c|c|c|c|c|c|c|}
\hline & Tobin's Q & GENDER & GROWTH & LEV & SIZE & BIG4 & DUAL & IND \\
\hline Tobin's Q & 1.000 & & & & & & & \\
\hline GENDER & $0.187^{* * *}$ & 1.000 & & & & & & \\
\hline GROWT & 0.019 & 0.023 & 1.000 & & & & & \\
\hline LEV & -0.044 & $0.201^{* * *}$ & -0.057 & 1.000 & & & & \\
\hline SIZE & -0.012 & $-0.137^{* * *}$ & -0.017 & $-0.148^{* * *}$ & 1.000 & & & \\
\hline BIG4 & -0.013 & $0.088^{* *}$ & -0.029 & 0.017 & $-0.092^{* *}$ & 1.000 & & \\
\hline DUAL & $0.065^{*}$ & -0.019 & -0.031 & 0.040 & $0.137^{* * *}$ & -0.033 & 1.000 & \\
\hline IND & -0.026 & $-0.166^{* * *}$ & -0.047 & $-0.222^{* * *}$ & $0.193^{* * *}$ & $-0.226^{* * *}$ & $-0.091^{* *}$ & 1.000 \\
\hline
\end{tabular}

Note: Table 4 represent the Pearson's correlation coefficients. The variables are as follows: Tobin's $Q$ which represents the firm financial performance. GENDER is the independent variable; The Control variables are: GROWTH; LEV; SIZE; BIG4 (PricewaterhouseCoopers, Deloitte \& Touche, Ernst\& Young and KPMG); DUAL; IND (Classifies into 1. Investment services 2. Insurance 3. Mortgages 4. Investment Trust 5. Banking Services). YED (The year's cover from 2000 to 2011). *** Significant at $1 \%$ level, ** Significant at $5 \%$ level, * Significant at $10 \%$ level. 
Table 5: Tobin's Q Regression Results

\begin{tabular}{|c|c|c|}
\hline & (Random Effects) & (Fixed Effects) \\
\hline & Tobin's Q (p-value) & Tobin's Q (p-value) \\
\hline GENDER & $4.921(0.00)^{6 * t}$ & $4.731(0.00)^{\mathrm{stw}}$ \\
\hline GROWTH & $1.596(0.03)^{*}$ & $1.765(0.03)^{* t}$ \\
\hline LEV & $0.110(0.66)$ & $0.117(0.65)$ \\
\hline SIZE & $0.125(0.44)$ & $0.192(0.29)$ \\
\hline BIG4 & $-4.216(0.43)$ & \\
\hline DUAL & $4.929(0.06)^{*}$ & \\
\hline Insurance-2 & $0.586(0.89)$ & \\
\hline Mortgages-3 & $6.993(0.10)$ & \\
\hline InvestTrust 4 & $18.699(0.01)^{t * t}$ & \\
\hline Banking-5 & $0.865(0.83)$ & \\
\hline Constant & $2.484(0.73)$ & $5.976(0.00)^{* *+}$ \\
\hline$N$ & 756 & 756 \\
\hline$R^{2}$ & & 0.077 \\
\hline $\mathrm{p}$ & 0.000 & 0.001 \\
\hline
\end{tabular}

Note: This table represents the RE and FE estimation on the relationship between board gender diversity and firm financial performance. The number of observation is 756 ; the $\mathrm{R}^{2}$ and the $\mathrm{p}$-value are all significant. The variables are defined as follows: Tobin's $\mathrm{Q}$ is the ratio of total assets minus book value of equity plus market value of equity to total assets. GENDER: Here represent the number of female on a corporate board. GROWTH: is defined as the ratio of sales growth to total assets growth. LEV: is defined as the Percentage of total debt to total assets. SIZE: Is defined as the natural log of total assets. BIG4: are (PricewaterhouseCoopers, Deloitte \& Touche, Ernst\& Young and KPMG). DUAL: Is defined as a situation where the firm is cross-listed in other countries. IND: classifies into 1. Investment services 2. Insurance 3. Mortgages 4. Investment Trust 5. Banking Services. The year's chosen for the research is from 2000 to 2011 . *** significant at $1 \%$ level, ** significant at 5\% level, * significant at $10 \%$ level. 


\begin{tabular}{|l|r|r|}
\hline & \multicolumn{1}{|c|}{ Pre-Crisis } & \multicolumn{1}{c|}{ Post-Crisis } \\
\hline & Tobin's Q (p-value) & Tobin's Q (p-value) \\
\hline GENDER & $5.456(0.00)^{* * *}$ & $2.698(0.26)$ \\
\hline GROWTH & $0.218(0.76)$ & $-2.002(0.13)$ \\
\hline LEV & $0.372(0.09)^{*}$ & $-0.368(0.36)$ \\
\hline SIZE & $-0.013(0.89)$ & $-0.370(0.09)^{*}$ \\
\hline BIG4 & $-1.399(0.39)$ & $-9.491(0.05)^{* *}$ \\
\hline DUAL & $3.272(0.01)^{* *}$ & $9.449(0.00)^{* * *}$ \\
\hline Insurance-2 & $2.633(0.22)$ & $4.174(00.26)$ \\
\hline Mortgages-3 & $6.015(0.01)^{* * *}$ & $15.360(0.00)^{* * *}$ \\
\hline Invest Trust4 & $18.877(0.00)^{* * *}$ & $25.220(0.00)^{* * *}$ \\
\hline Banking-5 & $3.016(0.16)$ & $3.548(0.35)$ \\
\hline Constant & $-1.253(0.68)$ & $10.360(0.10)^{*}$ \\
\hline$N$ & 441 & 189 \\
\hline$R^{2}$ & 0.145 & 0.199 \\
\hline$p$ & 0.000 & 0.000 \\
\hline
\end{tabular}

Note: The table above shows the pre/post financial crisis result when firms have women representations on their corporate board. The result shows 441 and 189 number of observations for the pre/post financial crisis respectively. The $R^{2}$ shows 0.145 and 0.199 for both the pre/post crisis period and the $\mathrm{p}$-value are significant in the regression model. The variables are defined as follows: Tobin's $Q$ is the ratio of total assets minus book value of equity plus market value of equity to total assets. GENDER: Here represent the number of female on a corporate board. GROWTH: is defined as the ratio of sales growth to total assets growth. LEV: is defined as the Percentage of total debt to total assets. SIZE: Is defined as the natural log of total assets. BIG4: are (PricewaterhouseCoopers, Deloitte \& Touche, Ernst\& Young and KPMG). DUAL: Is defined as a situation where the firm is cross-listed in other countries. IND: classifies into 1. Investment services 2. Insurance 3.Mortgages 4.Investment Trust 5. Banking Services. $* * *$ significant at $1 \%$ level, ** significant at 5\% level, * significant at $10 \%$ level. 